Brit. J. vener. Dis. (1958), 34, 258.

\title{
OBITUARY
}

\section{DAVID NUNES NABARRO}

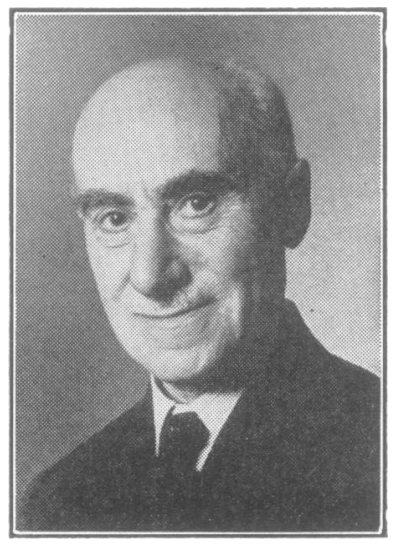

Dr. David Nabarro died on October 3, 1958, aged 84 , and much has already been said of his contributions to pathology and tropical medicine, but among venereologists he will always be remembered as a founder member and Past President of the M.S.S.V.D. and for his work on congenital syphilis, which culminated in a monograph published in his eightieth year!

In 1917, in addition to his duties as pathologist to the Hospital for Sick Children, Great Ormond Street, he started a clinic for the treatment of congenital syphilis, and this flourished until 1939 when, at the outbreak of war, the evacuation of hospitals, bearing, as Trotter said, all the diagnostic marks of panic, resulted in the closure of the clinic and the scattering of its patients. Such of them as could be reached by letter were invited to attend at the Whitechapel Clinic where, during the war, Nabarro used to come and examine his former patients' records and thus keep up his data while preparing for his monograph on congenital syphilis.

As assistant to Nabarro in the last three or four years before he retired early in 1939, I was greatly impressed with his ability to get and keep the confidence of his little patients and their parents, many of whom he also treated. It was impressive to see a child walk calmly into the clinic, sit down, and confidently put an already bared arm across the table where venepuncture was performed either for injecting arsphenamines or for withdrawing blood.

Years after treatment and sometimes when his patients had grown up and had children of their own, they would visit Nabarro whom they looked upon with obvious respect and affection.

Though he was essentially a kindly man three things roused his anger, which he expressed with a surprising pungency made all the more forceful by the absence of the cruder Anglo-Saxon expletives. The reluctance of medical men to have routine serum tests for syphilis carried out in pregnant women, neglect to examine the parents and siblings of a child found to have congenital syphilis, and finally the infamously low standards of antisyphilitic treatment in many otherwise admirable and famous institutions: all these called for and received from Nabarro the most impassioned denunciation. As he was a pioneer in the systematic management of congenital syphilis so he campaigned unceasingly for routine serological tests for syphilis in pregnant women, and before he died had the satisfaction of seeing most of his ideas accepted as normal practice.

F.R.C. 